KIDDO : JURNAL PENDIDIKAN ISLAM ANAK USIA DINI

http://kiddo@iainmadura.ac.id

E-ISSN : 2716-1641; P-ISSN: 2716-0572

\title{
Pendidikan Seks untuk Anak Usia Dini: Sebuah Upaya Preventif Untuk Menghindarkan Anak dari Bahaya Child Sexual Abuse
}

\author{
Siti Rohmaturrosyidah Ratnawati \\ Institut Agama Islam Negeri Ponorogo, Indonesia \\ rohmah.rosyidah@gmail.com
}

\begin{tabular}{|c|c|}
\hline Abstract & \\
\hline $\begin{array}{l}\text { The phenomenon of child sexual abuse is a problem } \\
\text { that continues to haunt anyone, especially parents. } \\
\text { The innocence and ignorance of children are the } \\
\text { reasons of why they often become the target of } \\
\text { sexual abuse. For this reason, sex education is very } \\
\text { important to give to children from an early age. } \\
\text { Through this paper, the author examined in depth } \\
\text { about sex education for early childhood by focusing } \\
\text { its study on two discussion points, namely: material } \\
\text { and strategies for sex education in early childhood. } \\
\text { The method used in this research is library research. } \\
\text { The results showed that sex education for early } \\
\text { childhood can be done by providing sex education } \\
\text { material through several strategies including } \\
\text { introducing limbs and their functions, teaching } \\
\text { children to be able to clean their own intimate areas, } \\
\text { understanding body parts that should not be seen } \\
\text { and touched by others, teaching the concept of sex } \\
\text { differences, motivating children to dare to say "no" } \\
\text { when someone else touches their banned parts of the } \\
\text { body and dare to ask for help and report to parents } \\
\text { when it happens. In addition, parents also need to } \\
\text { provide children with positive digital literacy when } \\
\text { they begin to get to know or get close to gadget, } \\
\text { internet, and social media. Maximum attention and } \\
\text { supervision from parents and educators are also } \\
\text { somethings that should not be forgotten to maximize } \\
\text { the process of sex education for children. }\end{array}$ & $\begin{array}{r}\text { Keywords: } \\
\text { Sex education; } \\
\text { Early childhood; } \\
\text { Child sexual abuse. }\end{array}$ \\
\hline \multicolumn{2}{|l|}{ Abstrak } \\
\hline $\begin{array}{l}\text { Fenomena pelecehan seksual pada anak (child sexual } \\
\text { abuse) merupakan permasalahan yang terus } \\
\text { menghantui siapapun, khususnya para orang tua. } \\
\text { Kepolosan dan ketidaktahuan anak-anak merupakan } \\
\text { salah satu sebab mengapa mereka seringkali } \\
\text { menjadi sasaran tindakan pelecehan seksual. Untuk } \\
\text { itu, pendidikan seks menjadi hal yang tak kalah }\end{array}$ & $\begin{array}{c}\text { Kata Kunci: } \\
\text { Pendidikan seks; } \\
\text { Anak usia dini; } \\
\text { Pelecehan seksual } \\
\text { pada anak. }\end{array}$ \\
\hline
\end{tabular}


penting untuk diberikan kepada anak sejak dini. Melalui makalah ini, penulis mengkaji secara mendalam tentang pendidikan seks untuk anak usia dini dengan memfokuskan kajiannya pada dua poin pembahasan, yaitu: materi dan strategi pendidikan seks pada anak usia dini. Metode yang digunakan dalam penelitian ini adalah library research. Hasil penelitian menunjukkan bahwa pendidikan seks untuk anak usia dini dapat dilakukan dengan memberikan materi pendidikan seks melalui beberapa strategi yang diantaranya adalah mengenalkan anggota tubuh beserta fungsinya, mengajarkan anak untuk bisa membersihkan area intim mereka sendiri, memahamkan bagian tubuh yang tidak boleh dilihat dan disentuh orang lain, mengajarkan konsep perbedaan jenis kelamin, memotivasi anak untuk berani berkata "tidak" saat ada orang lain yang menyentuh bagian tubuh mereka yang terlarang dan berani meminta tolong dan melaporkan kepada orang tua ketika hal tersebut terjadi.Selain itu, orang tua juga perlu membekali anak-anak dengan literasi digital yang positif saat mereka mulai mengenal atau dekat dengan gadget, internet, dan media sosial. Perhatian dan pengawasan maksimal dari orang tua dan pendidik juga merupakan hal yang tidak boleh terlupakan untuk memaksimalkan proses pendidikan seks bagi anak.

Diterima : 18 Oktober 2020.; Direvisi: 6 Januari 2021; Diterbitkan: 26 Februari 2020

http://doi.org/10.19105/ kiddo.v2i1.4216

(C) 2021 Siti Rohmaturrosyidah Ratnawati

This is an open access article under the CC-BY-NC license

\section{Pendahuluan}

Maraknya kekerasan dan pelecehan seksual bukan hanya mengancam remaja dan orang dewasa, akan tetapi juga anak-anak. Pelecehan seksual pada anak atau yang juga disebut dengan istilah child sexual abuse yaitu suatu bentuk perilaku kejahatanyang berkonotasi seksual terhadap anak yang dilakukan oleh orang dewasa atau remaja yang lebih tua dengan menjadikan anak sebagai media rangsangan seksual.Bentuk pelecehan seksual terhadap anak seringkali terjadi berupa tindakan meminta anak atau menekan seorang anak untuk melakukan aktivitas seksual, memberikan paparan yang tidak senonoh dari alat kelamin untuk anak, menampilkan pornografi atau pornoaksi untuk anak, melakukan hubungan seksual terhadap anakanak, kontak fisik dengan alat kelamin anak, menjadikan anak sebagai alat untuk memproduksi konten pornografi anak(Anhusadar \& Rusni, 2016, hal. 54-55) dan aksi kekerasan baik verbal (ancaman dan 
intimidasi) maupun fisik (paksaan untuk melayani si pelaku hingga berujung perkosaan).

Sebagaimana kita ketahui bahwa di berbagai media massa baik surat kabar, majalah, internet, maupun televisi telah banyak diberitakan sekian banyak kasus kejahatan seksual yang dilakukan oleh oknum-oknum tak bertanggungjawab dengan menjadikan anakanak sebagai korbannya. Diantara sederet kasus pelecehan seksual terhadap anak yang sangat menggemparkan masyarakat Indonesia adalah kasus pelecehan(dari tindakan merayu, meraba, sampai sodomi) yang telah dilakukan oleh Andri Sobari alias Emonkepada lebih dari 100 anak di bawah umur di Sukabumi Jawa Barat pada tahun 2014. Hal ini membuat pemerintah daerah Sukabumi menetapkan kasus tersebut sebagai kejadian luar biasa (KLB)(Liputan6, 2014).

Tidak berhenti di situ saja, Komisi Perlindungan Anak Indonesia (KPAI) menyatakan bahwa di sepanjang tahun 2019, ada sebanyak 21 kasus kekerasan seksual dengan jumlah korban mencapai 123 anak di beberapa satuan pendidikan yang terdiri atas 71 anak perempuan dan 52 anak laki-laki (Septianto, 2019). Tak kunjung membaik di awal 2020, sejumlah kasus kekerasan seksual pada anak masih mencuat. Diantaranya, kasus pelecehan seksual pada 12 siswi SD di Kecamatan Seyegan, Sleman, Daerah Istimewa Yogyakarta (DIY) oleh salah satu guru. Kasus tersebut diungkap polisi pada Januari 2020, namun sudah terjadi sejak Agustus 2019(Pinandhita, 2020).

Hal yang lebih mencengangkan lagi adalah bahwa pada beberapa kasus kejahatan dan pelecehan seksual yang pernah terjadi, anakanak di bawah umur tidak hanya menjadi korban, melainkan ada juga yang justru menjadi pelaku tindakan tersebut. Sebagai contoh adalah kasus pelecehan seksualterhadap bocah perempuan yang masih berusia 5 (lima) tahun yang dilakukan oleh 8 (delapan) orang teman sepermainannya yang juga masih di bawah umur di sebuah rumah kosong yang berada tak jauh dari rumah korban. Kejadian tersebut terjadi pada bulan Oktober tahun 2016 di daerah Jatinegara, Jakarta Timur (Rizki, 2016).

Pergaulan bebas dan sikap agresif yang terjadi pada anak-anak sebagaimana disebutkan di atas bisa saja dipicu dengan semakin berkembangnya teknologi informasi dan komunikasi di era digital ini yang tidak diimbangi dengan literasi digital yang baik dan pengawasan yang maksimal dari orang tua. Semakin liar dan tranparannya berbagai informasi yang dengan bebas dan mudah bisa diakes oleh siapapun tak terkecuali anak-anak kian memperparah potensi keterpaparan pornografi dan pornoaksi pada anak. Seringkali dijumpai anak-anak zaman sekarang memiliki hobi baru untuk berkumpul bersama temantemannya sambil mengoperasikan gawai mereka untuk berselancar di dunia maya dan media sosial, bermaingame online, menonton Youtube, dan lain-lain. Namun, sebagaimana kita ketahui bersama bahwa foto-foto, gambar-gambar, bahkan video yang erotis dan mengandung unsur pornografi seringkali terpampang jelas saat seseorang mengakses informasi atau fasilitas apapun melalui internet, tak terkecuali ketika mengakses game online, media sosial, Youtube, dan lain sebagainya. Dari situ, sangat mungkin sekali jika anak yang 
awalnya berniat hanya ingin bermain game online tapi karena rasa penasaran yang timbul dalam dirinya, pada akhirnya ia meng-klik gambar atau foto yang erotis tersebut. Dari keberanian yang pertama kali ia lakukan akhirnya akan membuatnya semakin penasaran dan ketagihan untuk mengakses informasi-informasi seputar hal tersebut.

Melihat peliknya permasalahan hari ini dengan semakin merebaknya kasus pelecehan dan kekerasan pada anak yang diperparah dengan tantangan dekadensi moral di era digital sebagaimana dipaparkan di atas mengingatkan semua pihak khususnya orang tua untuk senantiasa waspada dan mengawasi. Namun, sebetulnya waspada saja tidaklah cukup, akan tetapi perlu diimbangi dengan langkah kongkrit yang membuat anak mengenali secara dini akan bahaya yang mungkin mengancam dirinya, salah satunya bisa ditempuh dengan memberikan pendidikan seks kepada anak. Hanya saja, yang menjadi persoalan selama ini adalah masih berkembangnya anggapan bahwa jika anak terlalu dini untuk mendapatkan pendidikan seks, dikhawatirkan justru akan membuat anak menjadi dewasa sebelum waktunya. Anggapan ini tentu salah kaprah, karena sejatinya pendidikan seks untuk anak usia dini bukan soal mengajarkan anak untuk melakukan hubungan badan, akan tetapi dimaksudkan supaya anak memahami akan kondisi tubuhnya, kondisi tubuh lawan jenisnya, serta mampu menjaga dan menghindarkan dirinya dari kekerasan atau pelecehan seksual.

Pendidikan seks merupakan hal yang sangat urgent dan mendesak untuk diberikan kepada anak sedini mungkin. Anak perlu untuk dibekali pemahaman oleh orangtua mengenai sex education dengan tujuan untuk menjaga fitrah, keselamatan, kehormatan, dan kesucian anakanak. Namun, yang perlu diperhatikan dalam hal ini adalah mengenai materi, cara atau strategi apa yang tepat untuk digunakan dalam memberikan sex education kepada anak, khususnya anak usia dini. Sisi inilah yang perlu untuk dikaji secara mendalam. Maka, peneliti melalui tulisan ini berusaha untuk mengkaji secara mendalam serta menjawab dua pertanyaan penelitian berikut:a) materi apa saja yang perlu untuk diajarkan dalam pendidikan seks bagi anak usia dini?; dan b)bagaimanakah metode atau strategi pendidikan seks bagi anak usia dini?.

\section{Metode}

Untuk membahas fokus kajian sekaligus menjawab rumusan masalah dalam penelitian ini, peneliti menggunakan pendekatan penelitian deskriptif kualitatif dengan jenis penelitian kepustakaan (library research). Oleh karena itu, data-data utama yang dibutuhkan dalam penelitian ini diperolehmelalui penelusuran terhadap berbagai macam literatur baik buku, jurnal, maupun sumber referensi lainnya yang berkaitan dengan fokus pembahasan.

\section{Hasil dan Pembahasan}

Secara bahasa, seks atau yang dalam bahasa Inggris disebut sex berarti jenis kelamin, yaitu berkaitan dengan pemilahan biologis yang membedakan perempuan atau betina dengan laki-laki atau pejantan(Reber \& Reber, 2010, hal. 886). Namun sayangnya, istilah 
seks ini seringkali disalahartikan sebagai hubungan intim, sehingga hal ini seringkali menimbulkan kerancuan dan kesalahpahaman.

Adapun mengenai definisi pendidikan seks atau sex education yang juga seringkali disebut dengan pendidikan reproduksi sangatlah bervariasi, namun pada intinya antara satu definisi dengan definisi yang lain memiliki sisi persamaan. Di antaranya adalah pendapat Arthur S. Reber dan Emily S. Reber dalam Kamus Psikologi yang menyatakan bahwa sex education memiliki dua cakupan makna, yaitu makna secara luas dan sempit. Sex education dalam arti luas berarti pendidikan tentang semua aspek seks dan seksualitas seperti fisiologis, reproduksi, performa, emosi, dan antar-pribadi. Sedangkan dalam arti sempit, sex education berarti pendidikan yang hanya mencakup aspek fisiologis dan reproduksi seks(Reber \& Reber, 2010, hal. 888).

Menurut Reny Safita, pendidikan seks (sex education) adalah suatu pengetahuan yang perlu diajarkan mengenai segala sesuatu yang berhubungan dengan jenis kelamin. Ini mencakup mulai dari pertumbuhan jenis kelamin (kaki-laki atau perempuan), bagaimana fungsi alat kelamin sebagai alat reproduksi, bagaimana perkembangan alat kelamin itu pada wanita dan pada laki-laki, tentang menstruasi, mimpi basah dan sebagainya, sampai kepada timbulnya birahi karena adanya perubahan pada hormon-hormon, termasuk nantinya masalah perkawinan, kehamilan dan sebagainya(Safita, 2013, hal. 35).

Hampir senada dengan pendapat di atas, Abdullah Nashih Ulwan, seorang tokoh pendidikan Islam dari Halab menyatakan bahwa pendidikan seks adalah upaya mengajarkan, memberi pengertian, dan menjelaskan masalah-masalah yang menyangkut seks, naluri, dan perkawinan kepada anak sejak akalnya mulai tumbuh dan siap memahami hal-hal yang tersebut di atas. Hal ini bertujuan agar ketika anak mencapai usia remaja, mereka dapat memahami persoalan hidup, mengetahui mana yang halal dan yang haram, bahkan tingkah laku Islam yang luhur menjadi adat dan tradisi bagi anak tersebut(Ulwan, 2009).

Dari pemaparan kedua definisi tentang pendidikan seks di atas, dapat dipahami bahwa pendidikan seks tidak berkutat pada masalah pengenalan alat reproduksi dari segi fisiologis saja, akan tetapi juga mencakup banyak hal yang berkaitan dengan alat reproduksi baik secara langsung maupun tidak langsung yang tujuannya adalah agar anak memahami konsep-konsep tentang reproduksi dan materi-materi yang berhubungan tentanghal itu, serta mengetahui norma-norma yang melekat padanya,sehingga anak bisa menjaga dirinya dari perilaku yang menyimpang dan juga hal-hal yang berbahaya bagi dirinya. Maka, kedua definisi tentang pendidikan seks di atas lebih merujuk pada makna pendidikan seks secara luas.

Sedangkan Sarlito sebagaimana dikutip oleh Bayyinatul Muchtaromah, berpendapat bahwa pendidikan reproduksi adalah suatu informasi mengenai persoalan seksualitas manusia yang jelas dan benar, meliputi proses terjadinya pembuahan, kehamilan sampai kelahiran, tingkah laku seksual, hubungan seksual, dan aspek-aspek kesehatan, kejiwaan, dan kemasyarakatan. Masalah pendidikan seksual yang diberikan sepatutnya berkaitan dengan norma-norma 
yang berlaku di masyarakat, apa yang dilarang, apa yang dilazimkan dan bagaimana melakukannya tanpa melanggar aturan yang berlaku di masyarakat(Muchtaromah, 2008, hal. 9).

Meski secara sekilas definisi pendidikan seks ini terlihat lebih sempit dari kedua definisi sebelumnya, namun sebetulnya definisi ini juga masih merujuk pada pengertian pendidikan seks dalam arti secara luas karena tidak hanya memfokuskan kajiannya pada aspek reproduksi dari segi fisiologis, akan tetapi juga menyentuh ranah yang berkaitan dengan aturan atau norma yang berhubungan dengan alat reproduksi. Hal ini juga berarti bahwa mayoritas ahli pendidikan seks lebih merujuk kepada pengertian pendidikan seks secara luas karena dipandang lebih komprehensif dan mengandung tujuan yang mampu memenuhi kebutuhan sekaligus mampu menjawab tantangan yang ada.

Adapun yang dimaksud dengan anak usia dini bila dilihat dari jenjang pendidikan yang berlaku di Indonesia adalah anak-anak yang berusia 0-6 tahun, yaitu anak usia SD kelas rendah (kelas 1-3), Taman Kanak-kanak, Kelompok Bermain dan anak masa sebelumnya (masa bayi). Sedangkan menurut para pakar pendidikan anak, anak usia dini adalah kelompok anak yang berusia antara 0-8 tahun. Berdasarkan keunikan dalam pertumbuhan dan perkembangannya, anak usia dini terbagi menjadi tiga kelompok usia, yaitu: 1) masa bayi lahir sampai 12 bulan (infant), 2) masa toddler (batita), yaitu usia 1-3 tahun, 3) masa prasekolah (preschool) usia 3-6 tahun, dan 4) masa kelas awal SD (early primary school) 6-8 tahun(Mansur, 2011, hal. 88). Penulis dalam hal ini lebih mengacu kepada pendapat kedua, yaitu pendapat para pakar pendidikan anak yang menyatakan bahwa anak usia dini adalah mereka yang berusia sekitar 0-8 tahun.

\section{Urgensi Pendidikan Seks Bagi Anak Usia Dini}

Menurut Archibald D. Hart, Dekan Graduate School of Psychology di Fuller Theological Seminary Pasadena Californiasebagaimana dikutip oleh Muhamad Choirudin, bahwa naluri seks seseorang dikendalikan oleh bagian paling atas dari otak manusia, yaitu korteks. Korteks merupakan bagian otak yang mampu membantu manusia untuk dapat menyerap dan mempelajari berbagai macam hal. Dengan begitu, maka dapat dipahami bahwa organ pemicu seks pada manusia adalah otak,bukan sistem reproduksi(Choirudin, n.d., hal. 5). Maka jika muncul pertanyaan, "apakah pentingnya pendidikan seks?," maka jawaban yang paling sederhana untuk pertayaan tersebut adalah "karena otak perlu untuk diprogram dengan cara yang benar." Hal ini dikarenakan pikiran-pikiran di dalam otak manusia bukan hanya dapat menstimulus timbulnya dorongan seksual, akan tetapi sebaliknya juga mampu mencegahnya.

Selanjutnya, untuk lebih memahami urgensi pendidikan seks untuk anak usia dini, maka hal ini perlu juga dikaitkan dengan perkembangan otak pada anak usia dini. Anak usia dini adalah kelompok anak yang berada dalam karakteristik pertumbuhan dan perkembangan yang unik karena mereka memiliki pola pertumbuhan dan perkembangan yang sesuai dengan tingkat pertumbuhan dan 
perkembangan anak(Mansur, 2011, hal. 88). Para ahli sering mengatakan bahwa masa ini merupakan masa keemasan atau golden age anak. Pada usia ini, otak anak akan mengalami perkembangan yang sangat pesat, sehingga ia sangat mudah menerima rangsangan dari luar. Kesemuanya itu tidak akan mampu tergantikan pada masa mendatang. Menurut berbagai penelitian di bidang neurologi, terbukti bahwa 50\% kecerdasan anak terbentuk dalam kurun waktu 4 tahun pertama. Setelah anak berusia 8 tahun perkembangan otaknya mencapai $80 \%$ dan pada usia 18 tahun mencapai 100\%(Rachman, 2011, hal. 59). Dari sini, dapat dipahami bahwa perkembangan otak pada usia anak terjadi sangat pesat dan memberikan kontribusi yang sangat besar bagi kehidupan selanjutnya. Untuk itu, sejak usia ini, anak sudah harus mulai diberikan stimulus-stimulus positif dan beberapa hal atau prinsip yang disesuaikan dengan tahap perkembangan anak, agar benih-benih kepribadian yang unggul betulbetul mampu tertanam di dalam diri seorang anak.

Hal tersebut hampir senada dengan pendapat Kenneth Wolker dalam bukunya, The Handbook of Sex yang menyatakan bahwa pendidikan seks sangat perlu untuk diberikan bagi anak sejak usia dini karena pembentukan karakter dasar manusia terjadi pada masa kanak-kanak. Ahli psikoanalisa telah membuktikan tentang pengaruh yang baik dan tidak baik pada tahun-tahun pertama terhadap pertumbuhan karakter dasar anak. Pendidikan yang salah tentunya akan sangat berpengaruh terhadap perkembangan anak pada masamasa berikutnya. Hal ini berarti bahwa pendidikan seks pada anak usia dini diharapkan dapat meluruskan pemahaman dan perilaku seks anak(Mukri, 2015, hal. 9).

Selanjutnya, pendidikan seks juga sangat penting untuk diberikan kepada anak sedini mungkin mengingat semakin banyaknya kasuskasus pelecehan seksual (sexual abuse) terhadap anak atau yang juga dikenal dengan istilah child sexual abuse. Pendidikan seks diharapkan mampu memberikan konsep dasar tentang perbedaan jenis kelamin kepada anak sekaligus memberikan keterampilan untuk bisa menjaga dan membela diri ketika ada seseorang yang hendak melakukan tindakan pelecehan atau kekerasan seksual kepada mereka.

Selain itu, pendidikan seks juga sangat penting diberikan sejak dini dengan tujuan untuk membekali anak dengan tuntunan yang baikdan menjaga fitrah dan naluri seksualnya, sehingga saat mereka menginjak usia remaja, mereka tidak salah langkah, tau mana yang halal dan haram, mampu menjaga diri dan kehormatan mereka, serta tidak melalukan perilaku yang menyimpang dan melanggar normanorma agama dan budaya.

Adapun mengenai siapakah yang bertanggung jawab dalam memberikan pendidikan seks kepada anak terutama di usia mereka yang masih dini, maka lingkungan keluarga (khususnya orang tua) adalah jawabannya. Hal ini tidak lain karena keluarga berfungsi sebagai "transmiter budaya atau mediator" sosial budaya bagi anak(Muslimah, Maghfiroh, \& Astuti, 2020, hal. 3).Untuk itu, orang tua, baik ayah maupun ibu perlu memiliki pengetahuan yang luas dan mendalam mengenai pendidikan seks dan juga psikologi 
perkembangan anak. Hal tersebut tentu menjadi prasyarat bagi proses pendidikan seks yang menjadi tanggungjawab orang tua dalam lingkup pendidikan keluarga. Karena dengan begitu, diharapkan orang tua mampu menjadi sumber informasi dan teladan yang baik mengenai pendidikan seks bagi anak-anak mereka, agar anak tidak justru mendapatkan informasi yang salah mengenai hal tersebut mengingat semakin liarnya informasi di era digital ini. Keluarga menjadi pengawas terbaik bagi anak dalam mengontrol musik atau lagu yang didengar,majalah yang dibaca,acara televisi yang ditonton, baju yang dikenakan, serta konten-konten internet apa yang ditonton atau dibaca oleh mereka. Pendidikan seks ini sebaiknya diberikan dalam suasana akrab dan terbuka dari hati ke hati antara orang tua dan anak. Dalam hal ini, tentu kerja sama yang baik antara ayah dan ibu amat sangat diperlukan.

Al-Sayyid Ahmad sebagaimana dikutip oleh Bayyinatul Muchtaromah menyatakan bahwa pendidikan reproduksi bagi anak laki-laki sebaiknya ditangani oleh ayah, karena penjelasan seorang ayah kepada anak laki-lakinya akan lebih mengena. Demikian juga dengan anak perempuan yang diajak berbicara atau berdiskusi tentang pendidikan reproduksi oleh seorang ibu akan membentuk keakraban di antara keduanya. Namun dalam hal ini bukan berarti ayah tidak perlu berperan dalam pendidikan reproduksi bagi anak perempuannya dan begitu pula ibu untuk anak laki-lakinya. Psikologi kontemporer menegaskan pentingnya keterlibatan seorang ayah dalam pembentukan dan perkembangan anak baik anak laki-laki maupun perempuan, baik dalam hal pendidikan reproduksi atau yang berkaitan dengan hal lain(Muchtaromah, 2008, hal. 32).

Namun, hal ini bukan berarti bahwa tanggungjawab pendidikan seks hanya dipikul oleh orang tua saja, akan tetapi juga harus didukung oleh banyak pihak seperti masyarakat dan juga para pendidik di sekolah, khususnya ketika anak mulai mengenyam pendidikan formal di sekolah. Artinya, dalam melaksanakan tanggung jawab pendidikan seks bagi anak, diperlukan adanya sinergi yang baik antara tri pusat pendidikan yaitu pendidikan keluarga yang menjadi tanggungjawab orang tua, pendidikan sekolah yang diemban oleh pihak sekolah (kepala sekolah, guru dan lain-lain), dan pendidikan masyarakat yang merupakan tanggungjawab seluruh anggota masyarakat. Ketika ketiga mileu pendidikan ini bisa seiya sekata, mampu bersinergi dan bekerjasama dengan baik dalam memberikan pendidikan seks kepada anak, maka hasil dan tujuan yang diharapkan pun akan bisa tercapai dengan maksimal.

\section{Materi dan Strategi Pendidikan Seks bagi Anak Usia Dini}

Sudah tidak diragukan lagi bahwa pendidikan seks merupakan hal yang mendesak dan perlu untuk diberikan kepada anak sejak usia dini. Namun, untuk memberikan pendidikan seks kepada anak tentu dibutuhkan pemahaman mendalam baik dari materi apa yang cocok untuk anak seusia mereka serta strategi dan cara yang bagaimana yang tepat untuk diterapkan oleh orang tua kepada mereka agar maksud dan tujuan dari pendidikan seks yang dilakukan dapat tercapai 
secara maksimal, karena anak usia dini ini memiliki ciri tumbuh kembang yang unik.

Mengenai materi pendidikan seks, dalam buku panduan lengkap Comprehensive Sexuality Education (CSE) dari UNESCO, WHO dan badan Perserikatan Bangsa-Bangsa lainnya disebutkan bahwa sekurang-kurangnya ada sekitar delapan konsep kunci (key concept) materi yang perlu untuk diajarkan pada semua age groups(5-8 tahun; 9-12 tahun; 12-15 tahun; dan 15-18+ tahun). Kedelapan konsep kunci yang dimaksud meliputi: a) Hubungan (Relationship); b)Nilai, Hak, Budaya dan Seksualitas(Values, Rights, Culture and Sexuality); c) Memahami Konsep Gender(Understanding Gender); d) Kekerasan dan Bagaimana untuk tetap Aman(Violence and Staying Safe); e)Keterampilan untuk Kesehatan dan Kesejahteraan(Skills for Health and Well-being); f)Tubuh dan Perkembangan Manusia(the Human Body and Development); g)Seksualitas dan Perilaku Seksual(Sexuality and Sexual Behavior); h)Kesehatan Seksual dan Reproduksi(Sexual and Reproductive Health)(Unesco, 2018, hal. 35).

Kesemua konsep inti tersebut perlu untuk diajarkan dengan memperhatikan dan mengembangkannya ke dalam tiga domain tujuan pendidikan, yaitu pengetahuan (knowledge), sikap (attitudinal), dan keterampilan (skill). Pengetahuan memberikan landasan kritis bagi anak, sementara sikap membantu mereka membentuk pemahaman tentang diri mereka sendiri, seksualitas, dan dunia. Pada saat yang sama, keterampilan seperti komunikasi, mendengarkan, penolakan, pengambilan keputusan dan negosiasi,berpikir kritis, membangun kesadaran diri, mengembangkan empati, mengakses informasi atau layanan yang dapat diandalkan, akan memungkinkan peserta didik untuk mengambil suatu tindakan.

Bertolak dari delapan konsep kunci yang dirumuskan UNESCO dan WHO sebagaimana di atas, maka pendidikan seks pada anak usia dini dapat dimulai dengan mengenalkan anggota tubuh berserta fungsinya. Dalam hal ini, orang tua maupun pendidik bisa memanfaatkan media flash card, poster, video, atau anggota badan si anak sendiri. Untuk langkah selanjutnya, pada usia tertentu atau ketika anak sudah mulai bertanya dan memahami,anak juga perlu dipahamkan mengenai konsep dasar tentang perbedaan antara laki-laki dan perempuan. Hal ini kemudian bisa dikembangkan dengan mengenalkan organ vital dan fungsinya sekaligus memahamkan bahwa organ vital baik vagina maupun penis berfungsi tidak hanya sebagai jalan untuk buang air kecil, tetapi lebih dari itu, yakni sebagai salah satu alat untuk melakukan reproduksi. Namun, tentu hal ini harus disampaikan sesuai kebutuhan, usia, dan tahap perkembangan anak.

Berkaitan dengan pengenalan organ vital kepada anak usia dini, orang tua sebaiknya tidak menggunakan kata atau istilah samaran (yang selama ini sering terjadi) seperti 'burung' yang seringkali digunakan utuk menyebut alat kelamin laki-laki/penis. Sebenarnya penyebutan istilah seperti itu justru akan membuat bias pengetahuan pada anak. Bias pengetahuan ini bisa terjadi saat anak menginjak usia sekolah dan mulai bergaul dan bersosialisasi dengan orang lain di luar rumah. Dalam dunia pendidikan, bahasa yang biasa digunakan untuk 
menyebut sesuatu adalah bahasa formal, misalnya alat kelamin perempuan disebut vagina atau alat kelamin laki-laki disebut penis. Pengetahuan yang diperoleh anak di rumah dan disekolah tentang masalah seks menjadi berbeda hanya kerena penggunaan istilahistilah yang tidak seragam.

Langkah selanjutnya yang dapat dilakukan oleh para orang tua atau pendidik yaitu dengan mengajarkan anak untuk bisa membersihkan dan menjaga kebersihan area intim atau organ genitalnya sendiri. Untuk anak usia balita, orang tua perlu melakukan toilet training, yaitu latihan dan pembiasaan bagi anak usia balita untuk menggunakan toilet saat melakukan buang air. Hal ini dilakukan dengan tujuan melatih anak agar mampu mengontrol hajat alamiahnya dan terbiasa buang air pada tempat yang sesuai. Konsep ini perlu untuk diperkenalkan kepada anak sedini mungkin, yaitu sejak anak berusia 1 sampai 3 tahun(Rachman, 2011, hal. 90-91). Namun, tentu hal ini bukan hal yang mudah untuk dilakukan, tapi bukan berarti tidak bisa dilakukan. Pada awalnya, tentu akan terasa sulit, akan tetapi seiring dengan berjalannya proses tersebut, lambat laun hasilnya pun akan terasa dan berhasil, itulah habituasi.Selain bertujuan untuk menjadikan anak terbiasa mengontrol hajat alamiahnya, toilet training yang diberikan kepada anak juga dapat melatih anak untuk mandiri dan tidak bergantung kepada orang lain. Pelaksanaan toilet training pada anak usia dini ini secara tidak langsung juga menanamkan kepada anak agar tidak sembarangan mengizinkan orang lain untuk membersihkan alat kelaminnya.

Orang tua dan para pendidik juga perlu mengajarkan dan menekankan kepada anak bahwa ada bagian tubuh yang tidak boleh dilihat dan disentuh oleh orang lain. Hal ini sangat penting supaya anak mempunyai dan memegang prinsip untuk tidak sembarangan menampakkan anggota tubuh yang terlarang kepada orang lain serta tidak sembarangan mengizinkan orang lain untuk menyentuh anggota badan yang terlarang. Anak perlu diberikan pemahaman tentang bagian tubuh mana saja yang boleh disentuh orang lain dan bagian tubuh yang mana yang tidak boleh disentuh sama sekali oleh orang lain.

Selanjutnya, anak juga perlu dimotivasi untuk berani berkata "tidak" saat ada orang lain yang mencoba untuk menyentuh anggota tubuh yang terlarang serta berani berteriak dan meminta tolong ketika ada orang lain yang berusaha mengancamnya. Anak juga perlu diyakinkan supaya berani bercerita atau melaporkan apapun kepada keluarga tentang apa yang dialami di luar rumah saat mereka tidak diawasi oleh orang tua ataupun keluarga. Hal ini bertujuan supaya anak betul-betul berani dan memiliki power untuk melindungi diri (self-defence) mereka dari ancaman tindakan pelecehan atau kekerasan seksual yang mungkin saja mengintai dan mengancamnya. Oleh karena itu, orang tua harus bisa berperan sebagai teman yang bijak dan kooperatif bagi anak sehingga mereka bisa selalu merasa nyaman tanpa ada rasa takut untuk bercerita dan mengadukan segala hal yang dialaminya. Hal ini berangkat dari pernyataan Gordon dalam (Astuti, 2015, hal. 190) yang menyebutkan bahwa anak korban pelecehan dan kekerasan 
seksual seringkali tidak mau berterus terang untuk menceritakan kejadian yang dialami atau mengeluhkan penderitaan yang dirasakannya kepada orang tua. Hal tersebut kerapkali disebabkan oleh kurang baiknya pola komunikasi antara anak dan orang tua yang otoriter, anak selalu disalah-salahkan, dan anak tidak pernah dimintai pendapat oleh orang tuanya.

Hal yang tidak kalah penting dalam proses sex educationbagi anak usia dini adalah dengan memisahkan tempat tidur anak. Yang dimaksud dengan pemisahan tempat tidur anak di sini adalah pengondisian dua anak atau lebih untuk tidak tidur dalam satu selimut dan dalam satu tempat tidur, terlebih jika mereka (si kakak beradik) memiliki jenis kelamin yang berbeda(Muhammad Nur Abdul Hafidz Suwaid, 2010, hal. 556). Hal ini dimaksudkan untuk mengarahkan kecenderungan seksual anak ke arah yang baik agar naluri seksualnya tidak tumbuh secara negatif. Hal ini sesuai dengan tuntunan Rasulullah Saw. di dalam hadisnya yang menggambarkan perhatian beliau yang teramat besar terhadap perkembangan anak. Hal ini sebagaimana yang diriwayatkan oleh al-Hakim dalam kitab al-Mustadrak 'ala alShahihain(Al-Nisaburi, n.d., hal. 201)dengan komentar "shahih" berdasarkan syarat periwayatan Muslim yang disepakati oleh adzDzahabi dengan lafadz:

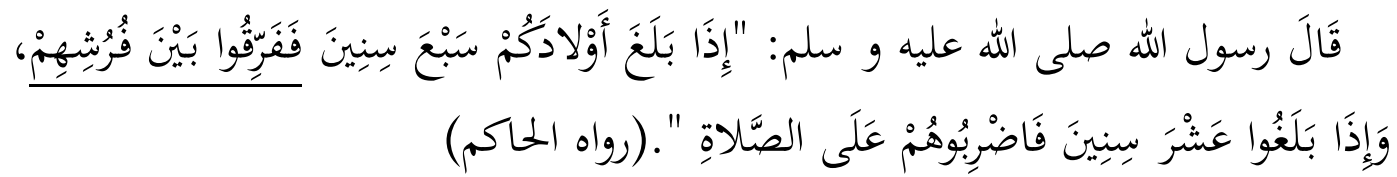

Artinya: Rasulullah Saw. bersabda: "Apabila anakanak kalian telah mencapai usia tujuh tahun, maka pisahkanlah tempat tidur mereka, dan apabila telah mencapai usia sepuluh tahun, maka pukulah mereka jika tidak mau melaksanakan shalat."

Terakhir, mengingat semakin kompleks dan rumitnya permasalahan pelecehan seksual dan dekadensi moral yang timbul sebagai salah satu dampak negatif dari perkembangan teknologi dan informasi yang massif di era digital, maka orang tua perlu untuk lebih aware dan bijak dalam memutuskan kapan waktu atau usia yang paling tepat untuk anak mulai dikenalkan dengan gadget, internet, dan media sosial. Selanjutnya, ketika anak sudah mulai dipercaya untuk mengenal gadget, internet, dan juga media sosial, hendaknya orang tua juga membekali anak dengan literasi digital yang positif. Literasi digital yang positif di sini bukan hanya mengajarkan anak supaya paham, cakap, dan terampil dalam menggunakan media digital, melainkan juga memahamkan dan membiasakan anak untuk bisa bersikap bijak dan bertanggungjawab dalam menggunakan media digital dan mengakses berbagai informasi dan fasilitas yang ada di internet. Meski demikian, orang tua juga hendaknya tidak mempercayakan sepenuhnya dan membiarkan anak begitu saja saat menggunakan gadget, melainkan perlu adanya perhatian dan pengawasanmaksimal namun tetap bersahabat dari orang tua untuk anak. 


\section{Kesimpulan}

Melihat rumitnya permasalahan hari ini dengan semakin merebaknya kasus pelecehan dan kekerasan pada anak yang diperparah dengan tantangan dekadensi moral di era digital, maka sudah seharusnya semua pihak, khususnya orang tua dan para pendidik betul-betul serius untuk memberikan pendidikan seks kepada anak sedini mungkin.Pendidikan seks untuk anak usia dini dapat dilakukan dengan memberikan materi pendidikan seks melalui beberapa strategi yang diantaranya adalah mengenalkan anggota tubuh beserta fungsinya, mengajarkan anak untuk bisa membersihkan area intim mereka sendiri (toilet training), memahamkan bagian tubuh yang tidak boleh dilihat dan disentuh orang lain, mengajarkan konsep perbedaan jenis kelamin, memotivasi anak untuk berani berkata "tidak" saat ada orang lain yang menyentuh bagian tubuh mereka yang terlarang dan berani meminta tolong dan melaporkan kepada orang tua ketika hal tersebut terjadi. Selain itu, anak juga perlu dibekali dengan literasi digital yang positif saat anak mulai mengenal atau dekat dengan gadget, internet, dan media sosial. Perhatian dan pengawasan maksimal dari orang tua dan pendidik juga merupakan hal yang tidak boleh terlupakan untuk memaksimalkan proses pendidikan seks bagi anak.

\section{Ucapan Terima kasih}

Penulis mengucapkan terima kasih kepada pengelola Jurnal Kiddo yang memberikan kesempatan kepada penulis untuk menerbitkan karya ilmiah ini.

\section{Daftar Pustaka}

Al-Nisaburi, A.-H. (n.d.). al-Mustadrak ala al-Shahihain, Jilid. I, Hadis No. 675. Beirut: Dar al-Kutub al-'Ilmiyyah.

Anhusadar, L. O., \& Rusni. (2016). Fenomena Kekerasan Seksual Terhadap Anak 35, no. 22 (): 54-55. Shautut Tarbiyah, 35(22), 51-68.

Astuti, H. P. (2015). Pada Anak Usia Dini. Proceeding Seminar Nasional Psikologi UMS: Selamatkan Generasi Bangsa dengan Membentuk Karakter Berbasis Kearifan Lokal, 190-197.

Choirudin, M. (n.d.). Urgensi Pendidikan Seks Sejak Dini Dalam Belenggu Kekerasan Seksual Terhadap Anak: Sebuah Upaya Preventif dan Protekstif.

Liputan6. (2014). Kejadian Luar Biasa Kasus Paedofil Emon, 114 Anak Jadi Korban. liputan6.com. Diambil dari https://www.liputan6.com/news/read/2048164/kejadian-luarbiasa-kasus-paedofil-emon-114-anak-jadi-korban

Mansur. (2011). Pendidikan Anak Usia Dini dalam Islam (4 ed.). Yogyakarta: Pustaka Pelajar.

Muchtaromah, B. (2008). Pendidikan Reproduksi Bagi Anak Menuju 
Aqil Baligh. Malang: UIN Malang Press.

Muhammad Nur Abdul Hafidz Suwaid. (2010). Prophetic Parenting: Cara Nabi Saw. Mendidik Anak. Yogyakarta: Pro-U Media.

Mukri, S. G. (2015). Pendidikan Seks Usia Dini Dalam Perspektif Hukum Islam. Mizan: Jurnal Ilmu Syariah, FAI Universitas Ibn Khaldun, 3(1), 1-20.

Muslimah, J., Maghfiroh, M., \& Astuti, R. (2020). Pola Asuh Orang Tua dan Perkembangan Moral Anak Usia Dini (Studi Kasus di Tk AlGhazali Jl. Raya Nyalaran Kelurahan Kolpajung Kecamatan Pamekasan Kabupaten Pamekasan). Kiddo: Jurnal Pendidikan Islam Anak Usia dini, 1(1), 1-9.

Pinandhita, V. (2020). 2020 Kekerasan pada Anak tak Menurun. lokadata.id. Diambil dari https://lokadata.id/artikel/2020kekerasan-pada-anak-tak-menurun

Rachman, M. F. (2011). Islamic Parenting. Jakarta: Erlangga.

Reber, A. S., \& Reber, E. S. (2010). The Penguin Dictionary of Psychology, Terj. Yudi Santoso. Yogyakarta: Pustaka Pelajar.

Rizki, D. (2016). Pelaku Pencabulan GS Masih di Bawah Umur, Polisi Gandeng BAPAS dan KPAI. wartakota.tribunnews.com. Diambil dari https://wartakota.tribunnews.com/2016/10/21/pelakupencabulan-gs-masih-di-bawah-umur-polisi-gandeng-bapas-dankpai

Safita, R. (2013). Peran Orang Tua dalam Memberikan Pendidikan Seksual pada Anak. Jurnal Edu-Bio, 4.

Septianto, B. (2019). 123 Anak Jadi Korban Kekerasan Seksual di Sekolah Selama 2019. tirto.id. Diambil dari https://tirto.id/123anak-jadi-korban-kekerasan-seksual-di-sekolah-selama-2019ep3D

Ulwan, A. N. (2009). Pendidikan Seks Untuk Anak Ala Nabi: Metode Islami Mengenalkan Seks Pada Anak Sejak Dini. Solo: Pustaka Iltizam.

Unesco. (2018). International Technical Guidance on Sexuality Education (2 ed.). France: Unesco \& WHO. 